\title{
PERBANDINGAN KOEFISIEN NMF DAN PROYEKSI BILINEAR SPACE SEBAGAI FITUR PADA PENGENALAN EKSPRESI WAJAH MANUSIA
}

\author{
William Salim \\ Computer Science Department, School of Computer Science, Binus University \\ Jl. K. H. Syahdan No. 9 Palmerah Jakarta Barat 11480 \\ wsalim@binus.edu
}

\begin{abstract}
NMF is one new developed method to make the part-based representation of non-negative data, such as human face image. NMF can reduce the dimension of high dimensional data such as multimedia data. In many researches,NMF can also used as a classification technique done by utilizing the extracted feature through NMF process. This article discusses about the classification technique of human face expression using NMF. This is done using NMF coeffisient and bilinear projection of face image. Some researches show the use of NMF coefficient in classification and some others use bilinear space projection. This research is conducted by simulating face espression recognition to the two available approaches and then comparing the accuracy and time efficiency aspect of the two methods. Through this research, it can be concluded that the use of NMF coefficient results in better accuracy compared to bilinear space projection, but bilinear space projection obtains better time efficiency.
\end{abstract}

Keywords: NMF, face expression recognition, bilinear space

\begin{abstract}
ABSTRAK
NMF merupakan salah satu metode yang baru dikembangkan untuk membuat representasi part-based dari data non-negative seperti gambar wajah. NMF dapat melakukan reduksi dimensi terhadap data dengan dimensi tinggi seperti data multimedia. Pada berbagai penelitian, NMF juga dapat digunakan sebagai teknik klasifikasi yaitu dengan memanfaatkan fitur yang dapat diekstrak melalui proses NMF. Artikel ini membahas mengenai teknik klasifikasi ekspresi wajah manusia menggunakan NMF, yaitu dengan memanfaatkan koefisien NMF dan hasil proyeksi gambar wajah ke bilinear space. Beberapa penelitian menunjukkan penggunaan koefisien NMF dalam klasifikasi dan pada penelitian lain digunakan hasil proyeksi bilinear space. Penelitian dilakukan dengan simulasi pengenalan ekspresi wajah terhadap kedua pendekatan tersebut dan kemudian membandingkan aspek akurasi dan efisiensi waktu dari kedua metode. Melalui penelitian ini dapat disimpulkan bahwa penggunaan koefisien NMF menghasilkan tingkat akurasi yang jauh lebih baik dibanding proyeksi bilinear space, tetapi proyeksi bilinear space memiliki efisiensi waktu yang lebih baik.
\end{abstract}

Kata Kunci: NMF, pengenalan ekspresi wajah, bilinear space 


\section{PENDAHULUAN}

Dalam beberapa tahun terakhir, peningkatan terhadap interaksi antara manusia dengan komputer merupakan suatu topik yang banyak menarik perhatian. Topik ini tidak hanya menarik perhatian peneliti di bidang ilmu komputer, melainkan juga peneliti dari berbagai bidang lainnya seperti psikologi, teknik mesin, neuroscience, dan lain-lain. Penelitian yang dilakukan bukan hanya bertujuan untuk meningkatkan antarmuka komputer, tetapi juga untuk meningkatkan respon yang dapat diberikan komputer terhadap interaksi yang diberikan.

Untuk dapat menghasilkan interaksi antara manusia dengan komputer yang efektif, diharapkan komputer dapat berinteraksi secara lebih alami dengan pengguna. Pada manusia, hal ini dapat dilakukan dengan adanya perbedaan intonasi suara, gerakan tubuh, dan emosi. Dalam komunikasi, ekspresi wajah merupakan salah satu faktor penting yang dapat menunjukkan emosi seseorang. Untuk itu komputer diharapkan dapat mengenali ekspresi tersebut untuk mendapatkan gambaran emosi pengguna. Hal ini bukanlah sebuah pekerjaan yang mudah bagi komputer mengingat beragamnya ekspresi yang dapat ditunjukkan setiap orang. Ekspresi senang seseorang belum tentu sama dengan ekspresi senang orang lainnya. Kompleksitas semakin bertambah dengan adanya perbedaan fisik seperti bentuk wajah dan warna kulit seseorang dengan orang lainnya. Posisi dan orientasi gambar wajah yang digunakan dalam proses pengenalan juga beragam sehingga menambah tingkat kesulitan.

Untuk dapat mengenali suatu gambar, gambar perlu diubah menjadi featurevector untuk dapat diproses. Featurevector merupakan kumpulan fitur yang unik dari suatu gambar. Fitur yang digunakan dapat berupa intensitas pada setiap pixel, histogram, edge, dan lain-lain. Proses ekstraksi fitur dari sebuah gambar umumnya menghasilkan jumlah fitur yang cukup banyak. Banyaknya jumlah fitur yang diekstrak dari sebuah gambar tidak menjamin adanya peningkatan akurasi dalam proses pengenalan. Selain itu kinerja yang dihasilkan juga menjadi tidak efisien. Oleh karena itu berbagai metode telah dirancang untuk mengurangi jumlah fitur yang berhasil diekstrak dengan tetap mempertahankan tingkat akurasi proses pengenalan.

Salah satu contoh algoritma reduksi dimensi yang cukup populer adalah Principal Component Analysis (PCA). Namun karena sifatnya yang holistik, PCA tidak dapat mengekstrak informasi atau fitur yang bersifat lokal. Sedangkan seperti yang dikatakan oleh Li, Hou, dan Zhang (2001), dalam kasus tertentu fitur yang bersifat lokal dapat menghasilkan akurasi pengenalan yang lebih baik. Maka dikembangkanlah algoritma Independent Component Analysis (ICA) yang dapat mengambil fitur yang bersifat lokal. Tetapi nilai negatif yang terdapat dalam basis image pada ICA menyebabkan terjadinya pembatalan nilai positif oleh nilai negatif. Karena pembatalan tersebut, basis image yang dihasilkan kurang dapat merepresentasikan bagian lokal dengan baik (Li et al., 2001).

Karena hal tersebut, dikembangkan metode Non-negative Matrix Factorization (NMF) yang dapat mengekstrak fitur lokal dari gambar dan tidak memiliki nilai negatif. Karena sifat ini, NMF dapat merepresentasikan begian-bagian lokal yang jika dikombinasikan secara additive dapat menghasilkan representasi keseluruhan dari wajah (Lee dan Seung, 1999). Namun, berdasarkan hasil penelitian yang dilakukan Li et al. (2001), NMF terbukti memiliki kinerja dan tingkat akurasi yang lebih buruk dari PCA. Maka dari itu dibuatlah beberapa variasi NMF seperti contohnya Local NMF (LNMF) dan Discriminant NMF (DNMF). Penelitian yang dilakukan oleh Bociu dan Pitas (2004) berhasil membuktikan LNMF dan DNMF menghasilkan hasil yang lebih baik ketika digunakan untuk mengenali ekspresi wajah.

Pada tahap klasifikasi, terdapat dua cara yang biasa digunakan pada NMF. Cara pertama menggunakan proyeksi gambar ke bilinear space dengan bantuan basis image. Cara lainnya adalah menggunakan koefisien NMF sebagai fitur. Pemilihan fitur yang tepat untuk digunakan untuk 
melakukan klasifikasi menjadi masalah utama yang muncul. Hal ini karena hingga saat ini belum ada penelitian yang membandingkan tingkat akurasi kedua fitur tersebut. Oleh sebab itu, diperlukan penelitian lebih lanjut untuk menentukan kelebihan dan kekurangan masing-masing fitur terutama dalam hal tingkat akurasi.

Tujuan penelitian ini adalah untuk membandingkan tingkat akurasi antara kedua fitur tersebut terutama dalam pengenalan ekspresi wajah manusia.

\section{METODE}

Penelitian ini menggunakan dua metodologi penelitian, yaitu studi pustaka dan percobaan laboratorium. Studi pustaka dilakukan dengan mengkaji artikel-artikel ilmiah yang berhubungan dengan klasifikasi ekspresi wajah dan NMF. Kemudian dirancang percobaan laboratorium untuk menguji tingkat akurasi dari kedua metode yang diteliti.

Percobaan yang dilakukan untuk mengenali ekspresi wajah manusia dengan menggunakan NMF terbagi menjadi dua fase yaitu fase offline dan fase online. Pada fase offline, dilakukan tahap pelatihan untuk menghasilkan model yang nantinya akan digunakan pada fase online. Pelatihan dilakukan dengan menggunakan gambar-gambar ekspresi wajah yang telah disiapkan sebelumnya. Pada fase online, model yang telah dihasilkan dari fase offline akan digunakan untuk mengenali ekspresi dari gambar ekspresi lainnya. Langkah percobaan yang dilakukan dapat dilihat secara lengkap pada Gambar 1.

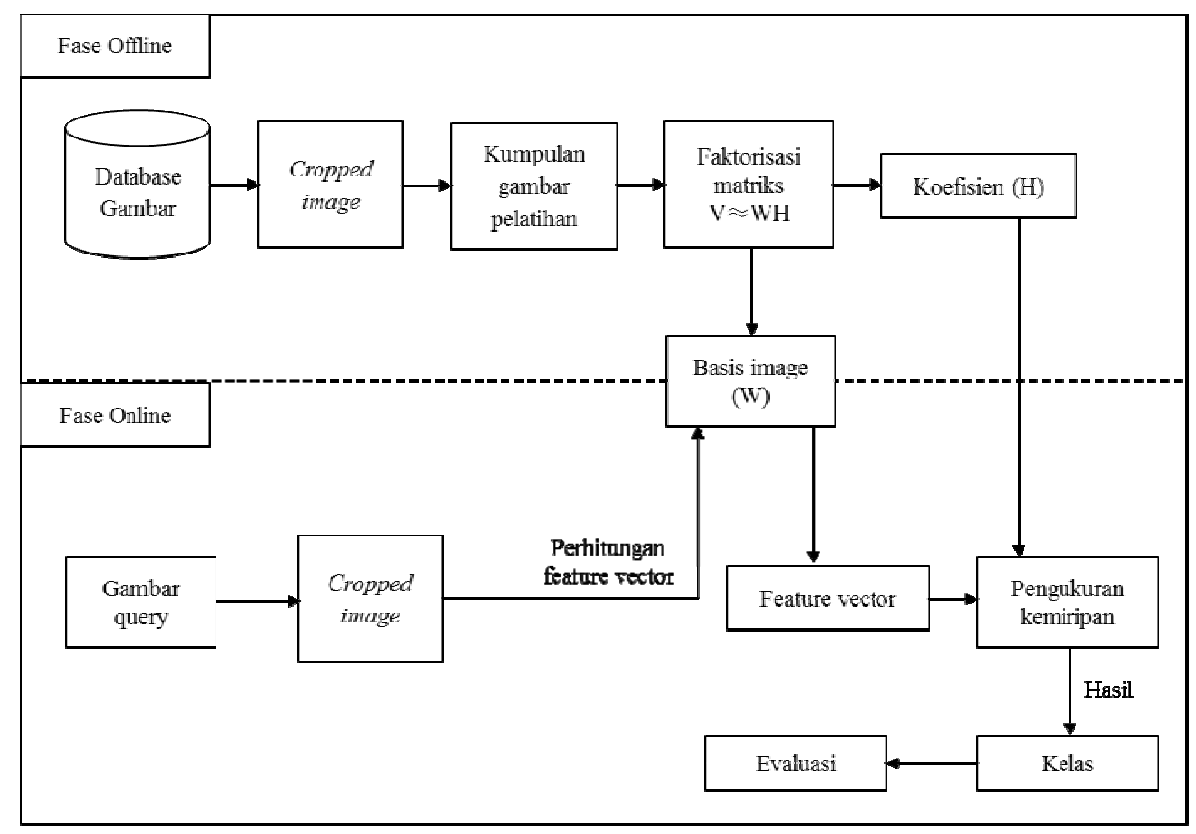

Gambar 1. Metodologi penelitian.

\section{Tinjauan Pustaka}

Pengenalan ekspresi wajah manusia oleh mesin dapat dideskripsikan sebagai interpretasi terhadap karakteristik ekspresi wajah manusia melalui algoritma matematis yang dilakukan dengan bantuan mesin (Raheja \& Kumar, 2010). 
Penelitian untuk dapat mengenali ekspresi wajah manusia dengan bantuan komputer sudah dimulai sejak dua dekade lalu. Mase (1991) menggunakan teknik optical flow untuk pengenalan ekspresi wajah. Lanitis, Taylor, dan Cootes (1995) menggunakan model bentuk fleksibel untuk mengenali identitas, jenis kelamin, dan ekspresi seseorang. Black dan Yacoob (1995) menggunakan local parametric model yang digunakan untuk mengikuti pergerakan wajah yang kemudian digunakan pada rule-based classifier untuk mengenali ekspresi. Kemudian Essa dan Pentland (1997) juga menggunakan optical flow dengan pendekatan berbasis regional untuk mengenali ekspresi wajah. Otsuka dan Ohya (1997) menggunakan optical flow dan Hidden Markov Model (HMM) untuk mengidentikasi ekspresi. Tian, Kanade, dan Cohn (2001) menggunakan action unit dan neural network, dimana action unit tersebut dapat menggambarkan pergerakan komponen wajah dalam berbagai ekspresi seperti yang ditulis oleh Ekman dan Friesen (1978). Cohen et al. (2003) menggunakan Bayesian network dan multilevel HMM sebagai classifier.

Di lain pihak, teknik reduksi dimensi seperti contohnya PCA juga telah berhasil digunakan untuk merepresentasikan dan mengenali ekspresi wajah seperti yang telah berhasil dilakukan oleh Cottrell dan Metcalfe (1991) serta Calder et al. (2001). ICA yang merupakan generalisasi dari PCA juga berhasil diterapkan oleh Fasel dan Luettin (2000) untuk pengenalan ekspresi wajah. Berikutnya Lee dan Seung (1999) mengembangkan algoritma NMF yang dinyatakan dapat merepresentasikan basis image secara lokal. Namun Li et al. (2001) menemukan bahwa NMF ternyata memiliki tingkat akurasi yang lebih buruk dibandingkan dengan PCA. Li juga menawarkan metode LNMF untuk mengatasi masalah yang ada pada NMF. Bociu dan Pitas (2004) lalu menggunakan kedua metode tersebut serta menawarkan metode DNMF yang terbukti lebih baik untuk mengenali ekspresi wajah.

Menurut Lee dan Seung (1999), NMF merupakan suatu metode faktorisasi matriks seperti halnya PCA, dimana kedua memiliki bentuk faktorisasi $\mathrm{V} \approx \mathrm{WH} . \mathrm{W}$ merupakan basis image sedangkan $\mathrm{H}$ merupakan encoding atau kombinasi koefisien dari setiap basis image. Kedua metode tersebut menghasilkan representasi basis image yang berbeda. PCA menghasilkan eigenfaces yang merupakan representasi terdistorsi dari keseluruhan wajah sedangkan NMF menghasilkan representasi fitur-fitur lokal dari setiap wajah. Bentuk basis image dari NMF ini memungkinkan wajah direkonstruksi hanya dengan bagian-bagian tertentu dari wajah. Hal ini dimungkinkan dengan adanya batasan non-negatif yang diterapkan pada kedua faktor yang dihasilkan.

Pada NMF, database gambar direpresentasikan dengan matriks V yang memiliki dimensi $n \times$ $m$ dimana $n$ merupakan jumlah pixel pada setiap gambar dan m merupakan jumlah gambar wajah yang terdapat dalam database tersebut. Matriks V difaktorisasi sehingga memenuhi bentuk

$$
V_{i \mu} \approx(W H)_{i \mu}=\sum_{a=1}^{r} W_{i a} H_{a \mu}
$$

Proses faktorisasi tersebut menghasilkan matriks $\mathrm{W}$ dan $\mathrm{H}$ yang masing-masing berdimensi $n$ $\times r$ dan $r \times m$. Nilai $r$ dipilih sedemikian sehingga persamaan $(n+m) r<n m$ terpenuhi. Dengan demikian maka terjadilah kompresi atau pengurangan terhadap dimensi database gambar.

Untuk mendapatkan hasil faktor yang paling mendekati $\mathrm{V} \approx \mathrm{WH}$, Kullback-Leibler (KL) divergence digunakan sebagai cost function seperti yang disebutkan oleh Lee (2001). Nilai terendah yang dapat dihasilkan KL divergence adalah nol.

$$
D(A \| B)=\sum_{i j}\left(A_{i j} \log \frac{A_{i j}}{B_{i j}}-A_{i j}+B_{i j}\right)
$$

Masalah berikut yang muncul adalah bagaimana cara meminimalkan nilai $\mathrm{D}(\mathrm{V} \mathrm{WH}-\mathrm{f})$ dengan tetap memenuhi syarat $\mathrm{W}, \mathrm{H} \geq 0$. Untuk mendapatkan $\mathrm{W}$ dan $\mathrm{H}$ yang tidak negatif, diterapkan multiplicativeupdaterules pada setiap iterasi. Dengan 


$$
\begin{aligned}
W_{i a} & =W_{i a} \frac{\sum_{\mu=1}^{m} \frac{V_{i \mu}}{(W H)_{i \mu}} H_{a \mu}}{\sum_{v} H_{a v}} \\
H_{a \mu} & =H_{a \mu} \frac{\sum_{i=1}^{n} W_{i a} \frac{V_{i \mu}}{(W H)_{i \mu}}}{\sum_{k} W_{k a}}
\end{aligned}
$$

Dengan adanya batasan non-negatif yang diberikan pada setiap faktor, setiap komponen yang berhasil dipelajari oleh NMF dapat dikombinasikan tanpa perlu melakukan pengurangan seperti yang terjadi pada ICA. Namun Li et al. (2001) menemukan bahwa bagian-bagian yang dipelajari oleh NMF ternyata tidak terlokalisasi seperti yang ditunjukkan oleh Lee dan Seung (1999). Li juga menemukan bahwa NMF bahkan menghasilkan akurasi yang lebih buruk dari PCA. NMF juga memerlukan iterasi yang lebih banyak untuk mencapai konvergensi. Gambar 2 berikut menampilkan basis image yang dihasilkan NMF.

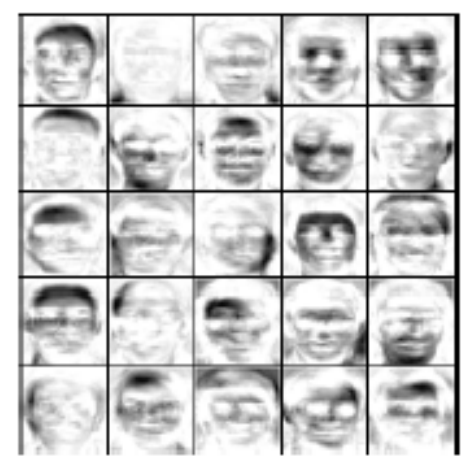

Gambar 2. Basis image yang dihasilkan NMF.

Untuk melakukan pengenalan terhadap sebuah gambar, Li et al. (2001) memproyeksikan gambar pelatihan ke dalam bilinear space dengan bantuan basis imagesehingga menjadi featurevector. Hal ini mirip seperti yang dilakukan pada PCA.

$$
F=W^{T} V
$$

Cara yang sama kemudian juga dilakukan terhadap gambar yang akan diklasifikasi.

$$
F^{\prime}=W^{T} V^{\prime}
$$

Pengenalan kemudian dapat dilakukan dengan menghitung Euclidean distance antara setiap hasil proyeksi ke bilinear space gambar query dengan hasil proyeksi gambar pelatihan. Gambar query akan diklasifikasikan sebagai anggota dari kelompok yang anggotanya memiliki Euclidean distance paling minimal.

Selain dengan menggunakan hasil proyeksi gambar ke bilinear space, klasifikasi juga dapat dilakukan dengan menggunakan koefisien $\mathrm{H}$ yang dihasilkan dari proses NMF seperti yang pernah dilakukan Benetos et al. (2006). Untuk melakukan ini, koefisien dari gambar query harus dihitung terlebih dahulu dengan menggunakan rumus

$$
H^{\prime}=W^{+} V^{\prime}
$$

Dimana $\mathrm{W}^{+}$merupakan Moore-Penrose generalized inverse matrix atau pseudoinverse dari matriks W. Koefisien dari gambar query kemudian dibandingkan dengan koefisien $\mathrm{H}$ dari gambar pelatihan.

Hingga saat ini, belum ada penelitian terhadap perbandingan tingkat akurasi klasifikasi yang dapat dihasilkan kedua pendekatan tersebut. 


\section{Dataset}

Penelitian ini menggunakan gambar ekspresi wajah manusia yang terdapat dalam database JAFFE yang dapat diakses melalui http://www.kasrl.org/jaffe info.txt. Database ini terdiri dari 213 gambar ekspresi wajah manusia yang berukuran $256 \times 256$ pixel. Database tersebut berisi sepuluh gambar wajah wanita Jepang yang diminta untuk menunjukkan beberapa ekspresi yang berbeda. Ekspresi yang ada di antaranya adalah ekspresi neutral, angry, happy, sad, fear, surprised, dan disgust (Gambar 3). Setiap orang memiliki kira-kira 21 gambar dengan ketujuh ekspresi yang telah disebutkan di atas.

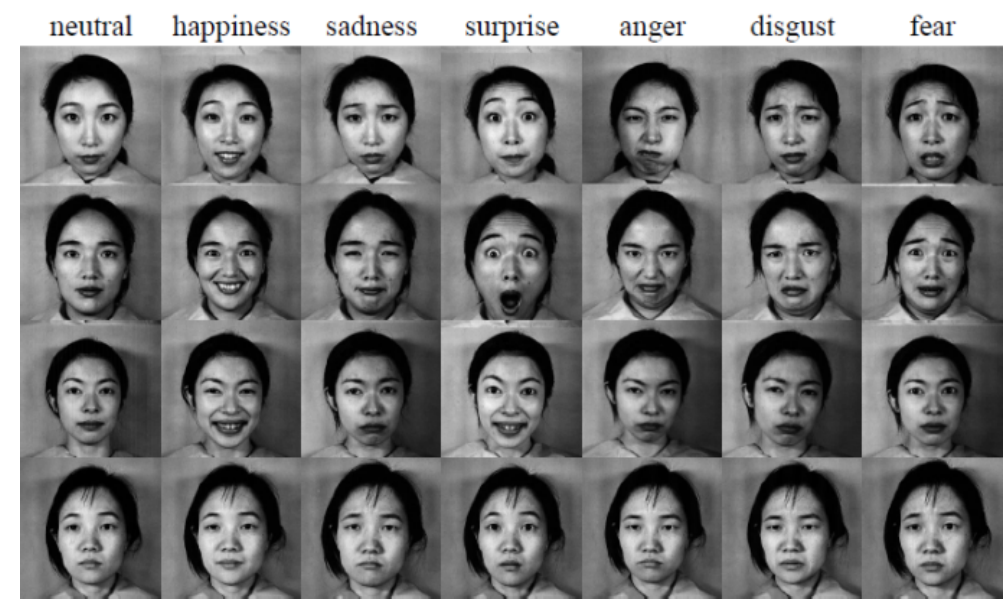

Gambar 3. Contoh gambar database JAFFE.

Untuk melakukan pengukuran terhadap efektifitas metode yang digunakan, akan dilakukan dua tahap yaitu tahap pelatihan dan pengujian. Untuk tujuan tersebut, database JAFFE akan dibagi menjadi dua bagian. Bagian pertama database berisi $80 \%$ dari jumlah keseluruhan data atau berjumlah 170 gambar. Bagian pertama ini akan digunakan pada tahap pelatihan. Bagian kedua berisi $20 \%$ dari jumlah keseluruhan gambar atau berjumlah 43 gambar. Bagian kedua ini akan digunakan dalam tahap pengujian. Pembagian database ini akan dilakukan secara acak. Pada penelitian ini, semua gambar ekspresi wajah yang digunakan akan di-downsample menjadi 100×100 pixel.

\section{HASIL DAN PEMBAHASAN}

\section{Eksperimen}

Eksperimen yang dilakukan untuk menguji tingkat akurasi klasifikasi kedua metode pendekatan dalam mengenali ekspresi wajah dimulai dengan tahap offline. Pada tahap ini, 170 gambar ekspresi yang telah dipilih secara acak akan melalui proses NMF untuk mendapatkan basis image W dan koefisien $\mathrm{H}$.

Langkah berikutnya dilakukan tahap online yaitu tahap klasifikasi. Pada tahap ini, 43 gambar ekspresi yang tidak termasuk dalam gambar yang digunakan pada tahap offline akan diklasifikasi. Klasifikasi dilakukan sebanyak dua kali menggunakan dua pendekatan yang berbeda, dengan koefisien NMF dan dengan hasil proyeksi gambar ke bilinear space. Hasil yang berupa persentase akurasi dan waktu klasifikasi dari kedua pendekatan kemudian dicatat sebagai bahan evaluasi. Eksperimen juga 
dilakukan pada jumlah basis image yang berbeda untuk mendapatkan data yang lebih komprehensif. Jumlah basis image yang digunakan adalah $n^{2}$ dimana $n=1,2, \ldots, 10$.

\section{Evaluasi}

Percobaan yang telah dirancang kemudian diimplementasikan menggunakan MATLAB 7.11. Hasil percobaan yang dilakukan dapat dilihat pada Gambar 4 dan 5.

Pada Gambar 4 terlihat grafik akurasi klasifikasi yang dihasilkan dengan menggunakan kedua pendekatan.Dari grafik tersebut terlihat akurasi dengan menggunakan koefisien NMF selalu menghasilkan hasil yang jauh lebih baik dibandingkan dengan menggunakan proyeksi bilinear space pada setiap percobaan. Akurasi tertinggi dengan menggunakan koefisien NMF diperoleh ketika basisimage berjumlah 64, yaitu mencapai $90,7 \%$. Hasil tertinggi dengan menggunakan proyeksi bilinear space juga diperoleh ketika basis image berjumlah 64, yaitu mencapai 72,09\%. Namun perlu diketahui bahwa hasil yang didapatkan pada setiap percobaan dengan jumlah basisimage tertentu tidak dapat dibandingkan secara langsung. Hal ini karena nilai awal matriks $W$ dan $H$ yang digunakan pada setiap percobaan dibuat secara acak sehingga memungkinkan hasil pelatihan satu percobaan dengan percobaan lainnya menjadi berbeda.

Pada Gambar 5 terlihat grafik waktu yang dibutuhkan oleh setiap metode untuk melakukan klasifikasi 40 gambar ekspresi wajah yang diberikan. Seiring dengan bertambahnya jumlah basis image, waktu yang diperlukan untuk melakukan klasifikasi juga menjadi bertambah. Hal ini karena semakin banyak jumlah basis image berarti semakin banyak pula jumlah fitur yang harus dihitung untuk menghitung kemiripan atara sebuah gambar dengan gambar lainnya.

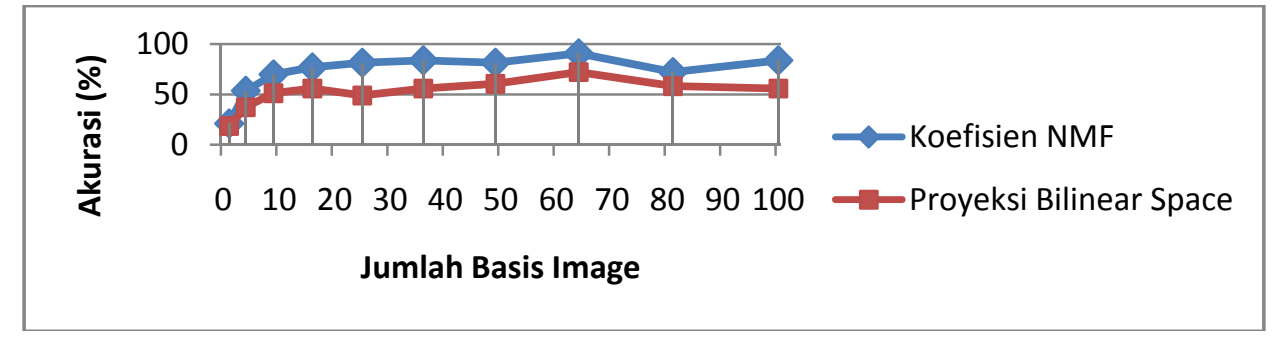

Gambar 4: Akurasi yang Diperoleh dengan Koefisien NMF dan Proyeksi Bilinear space

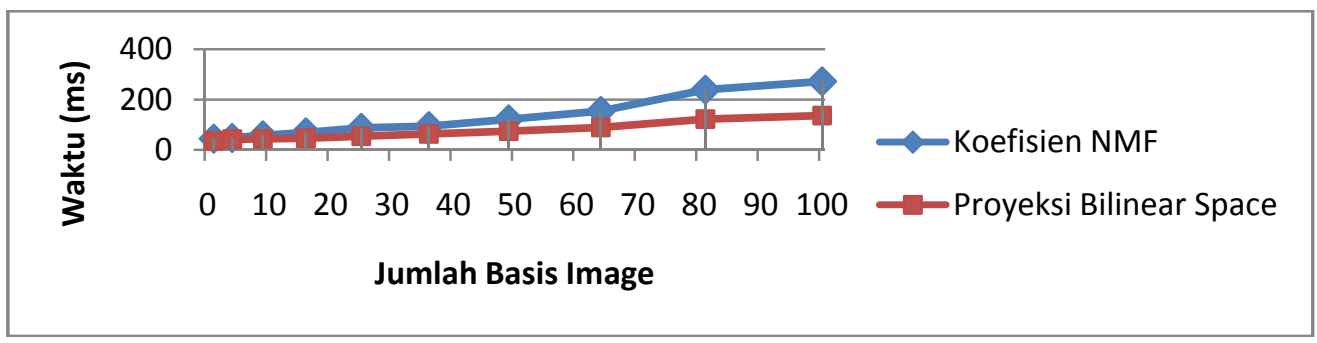

Gambar 5: Akurasi yang Diperoleh dengan Koefisien NMF dan Proyeksi Bilinear space

Selain itu dari grafik tersebut juga terlihat dengan menggunakan koefisien NMF, waktu yang yang dibutuhkan hampir mencapai dua kali lebih lama dibandingkan dengan menggunakan proyeksi ke bilinear space. Hal ini disebabkan untuk menghitung koefisien NMF dari gambar yang akan dikenali, pseudoinversedari basisimage $\mathrm{W}$ harus dihitung terlebih dahulu. Perhitungan peudoinverse merupakan operasi yang lebih kompleks jika dibandingkan dengan menghitung transpos dari matriks 
W seperti yang dilakukan saat memproyeksikan gambar ke bilinear space. Hasil yang lebih rinci dapat dilihat pada tabel 1 .

Tabel 1

Detail Data Hasil Eksperimen

\begin{tabular}{cccccc}
\hline & & \multicolumn{2}{c}{ Akurasi (\%) } & \multicolumn{2}{c}{ Waktu (ms) } \\
\cline { 3 - 6 } $\boldsymbol{n}$ & $\begin{array}{c}\text { Jumlah Basis } \\
\text { Image }\end{array}$ & $\begin{array}{c}\text { Koefisien } \\
\text { NMF }\end{array}$ & $\begin{array}{c}\text { Proyeksi Bilinear } \\
\text { space }\end{array}$ & $\begin{array}{c}\text { Koefisien } \\
\text { NMF }\end{array}$ & $\begin{array}{c}\text { Proyeksi Bilinear } \\
\text { space }\end{array}$ \\
\hline 1 & 1 & 20,93 & 18,6 & 44 & 35 \\
2 & 4 & 53,49 & 37,21 & 47 & 42 \\
3 & 9 & 69,77 & 51,16 & 57 & 43 \\
4 & 16 & 76,74 & 55,81 & 69 & 46 \\
5 & 25 & 81,4 & 48,84 & 87 & 54 \\
6 & 36 & 83,72 & 55,81 & 94 & 63 \\
7 & 49 & 81,4 & 60,47 & 121 & 74 \\
8 & 64 & 90,7 & 72,09 & 154 & 89 \\
9 & 81 & 72,09 & 58,14 & 239 & 122 \\
10 & 100 & 83,72 & 55,81 & 272 & 136 \\
\hline
\end{tabular}

\section{PENUTUP}

Berdasarkan hasil pengujian, dapat disimpulkan klasifikasi ekspresi wajah menggunakan koefisien NMF dapat menghasilkan akurasi yang jauh lebih baik daripada klasifikasi menggunakan hasil proyeksi gambar ke bilinear space, yaitu hingga 90,7\%. Namun, kekurangannya adalah waktu klasifikasi yang lebih lama dimana hampir mencapai dua kali lebih lama dari klasifikasi menggunakan proyeksi bilinear space.

Untuk pengembangan selanjutnya, penggunaan koefisien NMF untuk klasifikasi dapat diuji menggunakan dataset lain yang mungkin memiliki lebih banyak variasi wajah. Penggunaan koefisien NMF ini juga mungkin dapat implementasikan pada variasi metode NMF lainnya seperti LNMF, DNMF, 2DNMF, dan lain-lain dimana sangat memungkinkan dapat meningkatkan tingkat akurasinya.

\section{DAFTAR PUSTAKA}

Benetos, E., Kotti, M., \& Kotropoulos, C. (2006). Applying supervised classifiers based on nonnegative matrix factorization to musical instrument classification. IEEE International Conference on Multimedia and Expo, 2105-2108.

Black, M., \& Yacoob, Y. (1995). Tracking and recognizing rigid and non-rigid facial motions using local parametric models of image motion. Proc. International Conference on Computer Vision, 374-381.

Bociu, I., \& Pitas, I. (2004). A new sparse image representationalgorithm applied to facialexpression recognition: machine learning for signal processing. Proceedings of the 2004 14th IEEE Signal Processing Society Workshop, 539-548. 
Calder, A. J., Burton, A. M., Miller, P., Young, A. W., \& Akamatsu, S. (2001). A principal component analysis of facial expressions. Vision Research, 41, 1179-1208.

Cohen, L., Sebe, N., Garg, A., Chen, L., \& Huang, T. (2003). Facial expression recognition from video sequences: temporal and static modeling. Computer Vision and Image Understanding, 91(1-2), 160-187.

Cottrell, G., \& Metcalfe, J. (1991). Face, gender and emotion recognition using holons. Advances in Neural Information Processing Systems, 3, 564-571.

Ekman, P., \& Friesen, W.V. (1978). Facial Action Unit System: Investigator's Guide. California: Consulting Psychologists Press.

Essa, I., \& Pentland, A. (1997). Coding, analysis, interpretation, and recognition of facial expressions. IEEE Trans. Pattern Analysis and Machine Intelligence, 19(7), 757-767.

Fasel, B., \& Luettin, J. (2000). Recognition of asymmetric facial action unit activities and intensities. Proceedings of the International Conference on Pattern Recognition (ICPR 2000).

Lanitis, A., Taylor, C., \& Cootes, T. (1995). A unified approach to coding and interpreting face images. Proc. International Conf. on Computer Vision 368-373.

Lee D.D., \& Seung, H.S. (2001). Algorithms for non-negative matrix factorization. NIPS, 13, 556562.

Lee, D. D., \& Seung, H. S. (1999). Learning the parts of objects by non-negative matrix factorization. Nature, 401, 788-791.

Li, S. Z., Hou, X. W., \& Zhang, H. J. (2001). Learning spatially localized, parts-based representation. Int. Conf. Computer Vision and Pattern Recognition, 207-212.

Mase, K. (1991). Recognition of facial expression from optical flow. IEICE Trans, 74(10), 3474-3483.

Otsuka, T., \& Ohya, J. (1997). Recognizing multiple persons' facial expressions using HMM based on automatic extraction of significant frames from image sequences. Proc. Int. Conf. on Image Processing, 546-549.

Raheja, J. L., \& Kumar, U. (2010). Human facial expression detection from detected in captured image using back propagation neural network. International Journal of Computer Science and Information Technology, 2(1), 116-123.

Tian, Y., Kanade, T., \& Cohn, J. (2001). Recognizing action units for facial expression analysis. IEEE Transactions on Pattern Analysis and Machine Intelligence, 23(2), 97-116. 